\title{
A Brief Analysis of the Development Trend of Religious Education under the View of Non-Traditional Security
}

\author{
Ying Ma \\ Southeast National Education Research Center of Southwest University, Chongqing, China \\ Email: 461587213@qq.com
}

Received 8 June 2016; accepted 15 July 2016; published 18 July 2016

Copyright (C) 2016 by author and Scientific Research Publishing Inc. This work is licensed under the Creative Commons Attribution International License (CC BY). http://creativecommons.org/licenses/by/4.0/ cC) (7) Open Access

\begin{abstract}
In recent years, non-traditional security issues are increasingly prominent. In frontier minority areas, how to publicize the prevention from non-traditional security threats has become an important issue. If the government cannot fully recognize and utilize the position of minority ethnic education, including religious education, ill-intentioned people may take advantage of this loophole to damage mutual unity, progress and prosperity between all ethnic groups. Therefore, it is of realistic significance to study the role of a correct understanding of religious education in solving non-traditional security issues, as well as the differences between normal religious education and extreme ideological education.
\end{abstract}

\section{Keywords}

Non-Traditional Security, Religious Education, Development Trend

\section{Introduction about Non-Traditional Security}

National unity is a cornerstone of development and progress. It is an important matter concerning national unification, frontier consolidation, ethnic unity and social stability, as well as long-standing peace and flourishment of the Chinese nation to deal with national problems and handle national relationship properly. When handling ethnic relations, we must hold fast to the guiding principle of unity and progress, wage a resolute struggle against illegal and criminal behaviors in violation to ethnic unity and progress, distinguish "contradictions between enemies and ourselves" and "contradictions among people" correctly, discriminate, emphasize and maintain national security. National security includes traditional security issues like political, military and diplomatic and non-traditional security issues. Non-traditional security issues refer to all factors other than military, politi- 
cal and diplomatic conflicts that pose a threat to sovereignty and the overall survival and growth of human beings [1].

\section{Non-Traditional Security Issues and Religious Education}

Frontier minority areas are vulnerable to the impact of international ethnic issues and other factors. They are potential high-risk areas of non-traditional security issues in our country. With the development and change of non-traditional security issues, non-traditional security threats in frontier minority areas tend to "diffuse in" and "spill out" [2]. For this, we must plan in advance, pay high attention to the new dynamic of non-traditional security issues in minority areas, study precautious measures, construct minority areas into progressive demonstration zones of national unity and set up security and stability barriers in the national frontier.

In China, religious education is one of the most significant positions of traditional moral education for numerous minorities, including the Hui nationality. They follow the central spirit that "Han is inseparable from minorities, minorities are inseparable from Han and minorities are inseparable from one another”, take an active part in serving adherents, promote harmonious ethnic relations and make positive contributions to the great cause of mutual unity, progress and prosperity between all ethnic groups in China. In teaching how to prevent from non-traditional security threats, religious education has a special status and significance.

Once non-traditional security issues befall, they will threaten different groups in the society. The government must carry out safety education through a variety of means, including religious education. First of all, incorporate non-traditional security into religious education. At present, what Yunnan minority areas implement most in non-traditional security education is to publicize "anti-drugs and AIDS". In view of the current situation, we must strengthen non-traditional security education in religious education work and blend moral education. Secondly, set up non-traditional security education weeks and carry out universal non-traditional security education. Nowadays, non-traditional security issues are more and more severe. The form of threats is varied. By setting up non-traditional security education weeks, we allow more people in the society to understand the status of non-traditional security issues, enhance their awareness of non-traditional security issues and mobilize people to show care and offer help to those who are hurt. Thirdly, make use of media, such as newspapers, TV and network, etc. to carry out non-traditional security knowledge publicity and education. Since media information is spread in time, the spread content is intuitive and plain and the coverage is wide, people can cognize nontraditional security issues more comprehensively and quickly.

\section{The Complexity and Specialization of Non-Traditional Security Issues per se Require Strengthening Publicity and Education}

Non-traditional security issues, as an integral part of social governance, used to be handled by competent departments, according to the division of duties. But with the development of society, on the one hand, social information is highly developed. The exchange of all kinds of information becomes discorded. Negative information spreads more quickly. It is difficult for positive information to occupy a position in public opinions quickly. As a result, pubic groups often follow blindly and act on passion. This arouses more concern and greater impact. On the other hand, as economic and social development is in a "new normality", various social conflicts happen easily and frequently. Benefits between all social groups are increasingly differentiated. Intergroup antagonism is exacerbated. The degree of tolerance is reduced and forms a "domino" effect. A slight move in one part may affect the situation as a whole. All kinds of non-traditional security issues are prone to escalate into more severe social problems. When a non-traditional security problem happen, people often go beyond the event itself and extend to a series of problems, like national relations and religious policy, etc. Such an event may be "kidnapped" by public opinions wrongly and lead to censure on government and criticism on officials. This situation is particularly evident in cyberspace. On many website forums, "professional attackers" and "conflict-makers” etc. emerge. They turn normal discussions under the atmosphere of freedom of speech into attacks and abuses on government, society, morality, rule of law, region and group, etc.

Meanwhile, many of non-traditional security issues are very specialized and technical. There must be specialists to dispose these issues according to prescribed procedures. However, on the one hand, due to the complexity and correlation of non-traditional security issues, it is hard to solve many problems properly within the scope of one department. We must seek cooperation from other domains. On the other hand, relevant professional talents are concentrated in professional departments. Staff in other sectors is short of relevant knowledge and training, 
which often causes errors in inter-department coordination. They are at a total loss when facing some problems, which further hits the government's credibility and make no contribution to the solution of problems. Many problems involve multiple departments and require the whole society to participate. Though, as required by work, the government has set up coordinating bodies for revenant departments, due to unequal rights, duties and benefits and a lack of social participation, etc., in fact, duties still fall upon leading departments. The desire to participate, ability, condition and effect in other departments are very limited. Therefore, eventually, the key to solve problems is to reinforce publicity and education and improve the masses' ability and quality to dispose non-traditional security issues in an all-round way.

\section{Understanding Differences between Normal Religious Education and Extreme Ideological Education Correctly}

On March 1, 2014, after a terrorist attack happened in Kunming Railway Station, it aroused widespread attentions and reflections from all walks of life. It has become imperative to cut off the spread of extremism and prevent the emergence of new terrorists, while cracking down on terrorist crimes. Thereafter, within the territory of Yunnan Province, religious sites and religious educational institutions were scrutinized. During the scrutiny, it was found that children from the Hui nationality and other minorities who believed in Islam in Yunnan Province received good education and conformed to national policies and legislations, as well as social order and customs as a whole. But some extreme cases did appear [3]. Some lawbreakers took advantage of the platform of religious education, distorted facts on purpose and diffused extremist ideas. It had an adverse effect on some children. Although the local government has disposed the above situation in time, if we cannot find out the root cause, cut off the spreading route and distinguish it from normal religious education, similar situations would happen again, even spread from point to area and make innocent people get into trouble.

Normal religious education is an important channel for the Hui nationality to inherit ethnic and religious culture, while extreme ideological education is a kind of brainwash and propaganda for political, economic and other purposes. Owing to the special status of mosque in Hui and other minorities who believe in Islam, both of them regard mosque a chief propaganda venue. But there are still obvious differences between them.

First of all, the starting point of education is different. Normal education is normal education activities, mainly intended to spread religious cultural knowledge, inherit traditional ethnic culture and morality and serve the practical requirements of adherents in production and life. While extreme ideological education is illegal behaviors out of ulterior motive, intended to distort facts, instigate hatred, sow discords between ethnic groups, undermine harmony and stability in China and further encourage people to oppose our country and ethnic groups and violate laws and regulations.

Secondly, the teaching content is different. Normal religious education mainly imparts Koran, Al-hadìth and other religious classics, popularizes traditional cultural knowledge of the Hui nationality, teaches and guides adherents to "get on the right track" and "be virtuous". While extreme ideological education is covered under the cloak of religion. It instigates people to oppose the existing system, risk their life to endanger safety of other members of the society, by distorting facts and misinterpreting religious creeds.

Thirdly, the teaching method is different. Normal religious education gives priority to imparting knowledge, correctly interpreting classics, preaching in public, guiding positively and releasing positive energy. While extreme ideological education gives priority to distorting classics, preaching in secret, instilling privately and amplifying the dark side of society.

Fourthly, the teaching goal is different. The goal of normal religious education is to enable adherents to have a correct understanding of religious knowledge, inherit and carry forward complete traditional moral culture and achieve perfection and harmony between society, family and individuals through their own practice. While extreme ideological education tries to make people set up a wrong outlook of world, life and value, by instilling false information, to make people sacrifice for the ulterior motives of a few covert manipulators, by violating laws, regulations, social order and customs.

\section{The Education Mechanism of Normal Religious Education}

After hundreds of years of development, normal religious education has basically formed a complete set of internalization mechanism of traditional moral education. To take children-oriented religious education for example, generally speaking, there are three types of classes: training class per night in the spare time of national 
education; training class per weekend and training class during summer and winter vacations. These classes have two characteristics. First of all, they are held in the spare time of national education and won't conflict with national education. Secondly, in terms of content, they teach religious cultural knowledge and traditional morality, which are complementary to national education. Again, each type of class is divided into different stages, according to the number and level, etc. of students. During education, the main approaches are:

For beginners (junior class), generally imitation is adopted. Teachers lead students to recite Koran, watch religious activities and ritual procedures together, through constant observation, recitation and memorization. At this stage, children don't learn religious words or language, but keep imitating, form conditioned reflexes, build a strong first impression and lay a solid foundation for subsequent learning. According to a survey, even ten years later, many adults can still recall the knowledge they learn in childhood and recite the scriptures accurately.

For children with a certain foundation (intermediate class), generally consolidation and practice are adopted. The teaching content is divided into two parts. One is to strengthen learning content at the previous phase. The main method is to lead children to apply the knowledge they learn to all kinds of rituals, according to the requirements for religious activities. The other is to learn new knowledge as appropriate. The main method is to divide each lesson is into two stages. In the first stage, review knowledge taught in the last lesson. In the second stage, learn new knowledge. Repeat this cycle and form interlocking learning chains.

For children with preliminary independent thinking ability and fundamental knowledge (senior class), generally identity education is adopted. This stage will follow the practice of applying learned knowledge to actual religious activities and rituals and lets children to play a greater part in organizing, implementing and coordinating activities and undertake certain work tasks and duties. Meanwhile, during education, students mainly receive theory teaching and case teaching, while learning Arabic language and words. The main purpose is to explain the rationality and practicability of all sorts of canons, creeds and traditional ethnic moral culture, tease out all kinds of learned knowledge ideologically and theoretically, recognize its legitimacy and rationality, gradually establish individual rational judgments and develop a religious faith and codes of ethics that they identify with in emotion. This is a gradual process, which allows people to pursue a better life by means of sincerity, virtue and beauty and cultivates their love for society, concern for others and self-reliance. It is a process full of positive energy.

\section{The Education Mechanism of Extreme Ideological Education}

Extreme ideological education is anti-social and anti-humanistic. But it often presents an illusive image in front of people. During a survey, it is found that at an early stage, extreme ideological education often covers itself under the guise of "orthodox way", "orthodox religion" and "true faith" [4], etc. Some assert that they come from areas with a stronger religious culture. Some claim that their thoughts come from celebrities in certain religion domains. Still some claim that their thoughts originate from abroad. In a word, they want to fabricate a "high-class, great and noble" descent for themselves and pretend to be selfless, dedicated and disinterested gentlemen.

In teaching method, extreme ideological education often distorts canons, creeds and social reality. They amplify the dark side of society infinitely, to make the target object world-weary, pessimistic and extremely disappointed about social reality, etc. Meanwhile, they conceal their real intention, draw the target object over with petty favors under the pretext of "faith", "help" and "support", etc, depict a beautiful picture and make promises to them, such as give them a chance to study, go abroad, get sponsored or ascend to heaven, etc. Being disappointed with reality and highly-anticipated for the future, the target object develops psychological dependence on the practitioners of extreme ideological education unconsciously. After conditions are ripe, they make the target object do some simple things for them, gradually intensify and make them bogged down deeper and deeper. As a result, the target object develops a self-abandoned psychology, believes that now that there is no way back, why they shouldn't make a big deal and win over the fictitious promises. Since such behaviors are illegal, they often conceal themselves, contact each other in one way and rope in their relatives and friends. Under the cloak of religion and ethnic groups, these behaviors are often hard to perceive and guard against.

\section{Conclusion}

At present, non-traditional security issues are prevalent in frontier minority areas. Slow, insufficient, uncoordinated and unbalanced development is the main reason. Insufficient development is still a major contradiction in 
frontier areas. Likewise, some problems arising out of the practice of religious education are a normal phenomenon during the evolution of things. We shouldn't deny them simply, but strengthen guidance and standardization. If we don't preempt a position in ideology and public opinion, evil winds will become unscrupulous. In the face of difficulties, we mustn't turn a blind eye and keep dodging, but face the music and strive to make a difference. Development is a master key to all problems. Fundamentally, the problems with religious education can only be solved by our own development.

\section{References}

[1] Li, K.S. and Xue, L. (2012) Non-Traditional Security Theory: Concept, Genre and Characteristic. International Politics Quarterly, No.2.

[2] Luo, G. (2012) Research on Illegal Immigration and Its Governance in Ethnic Areas on Yunnan Border: Yao Autonomous County in Hekou for Example. Law Press.

[3] Yu, X.Q. (2003) Non-Traditional Security Analysis. Contemporary International Relations, No. 5.

[4] Zhuo, X.P. (2014) Guide Religion Actively and Guard against Extremist Ideas. Studies in World Religions, No. 6.

\section{Submit or recommend next manuscript to SCIRP and we will provide best service for you:}

Accepting pre-submission inquiries through Email, Facebook, Linkedin, Twitter, etc A wide selection of journals (inclusive of 9 subjects, more than 200 journals)

Providing a 24-hour high-quality service

User-friendly online submission system

Fair and swift peer-review system

Efficient typesetting and proofreading procedure

Display of the result of downloads and visits, as well as the number of cited articles

Maximum dissemination of your research work

Submit your manuscript at: http://papersubmission.scirp.org/ 